\title{
ТЕОРЕТИЧНІ ОСНОВИ ПОБУДОВИ МЕТОДИКИ ОЦІНКИ ПРОФЕСІЙНОГО РИЗИКУ, ПРИЙНЯТНОї ДЛЯ ПІДПРИЄМСТВ РІЗНИХ ВИДІВ ЕКОНОМІЧНОЇ ДІЯЛЬНОСТІ
}

\section{І. М. Ткалич}

Державна установа «Національний науково-дослідний інститут промислової безпеки та охорони праці» вул. Вавілових, 13, м. Київ,04060, Україна. E-mail: iratkalich@gmail.com

Відзначено, що діюча система управління охороною праці не забезпечує визначення пріоритетності профілактичних заходів з безпеки та гігієни праці, не сприяє запровадженню ефективного механізму економічного стимулювання роботодавців до створення належних, безпечних і здорових умов праці і не дає змоги роботодавцям вибирати дієвий спосіб управління охороною праці. Заходи реагування спрямовуються переважно на регулювання та посилення обов'язкових загальних вимог без урахування факторів ризику на виробництві. Проаналізовано світовий досвід з оцінки професійних ризиків. Враховуючи значну кількість існуючих методів оцінювання ризиків та неможливість створити універсальний метод, придатний для підприємств (організацій) будьякого виду економічної діяльності, наведено короткий опис, переваги та недоліки найбільш часто використовуваних в міжнародній практиці методів ідентифікації, аналізу і оцінювання ризику, їх поєднання або послідовнопаралельного застосування. Використання цих методів передбачає їх адаптацію до умов конкретного підприємства 3 урахуванням його специфіки. Найбільш привабливими для практичного використання можна вважати методи Елмері, Файн-Кінні та «Матриця наслідків / ймовірностей» через помірні вимоги до необхідних ресурсів, низьку ступінь невизначеності результатів та невисоку складність реалізації. За результатами проведених теоретичних досліджень розроблено методику оцінки професійного ризику, використання якої передбачає виконання визначеної послідовності етапів: організація робіт, ідентифікація небезпек, аналізування та оцінювання ризику, розробка та впровадження заходів. Заключний етап методики передбачає цілеспрямоване використання отриманих на попередніх етапах даних для обгрунтування заходів, спрямованих на усунення (за змогою) або мінімізацію ризиків. Для практичної реалізації викладеної методики необхідно розробити та впровадити інформаційну систему «Реєстр професійних ризиків». Ця система дозволить автоматизувати всі етапи, починаючи від збору даних, насамперед, про потенційні небезпеки та їх джерела, та закінчуючи розрахунком оцінки професійних ризиків на основі обраних методів.

Ключові слова:управління охороною праці, методи оцінки ризиків, інформаційна система.

\section{ТЕОРЕТИЧЕСКИЕ ОСНОВЫ ПОСТРОЕНИЯ МЕТОДИКИ ОЦЕНКИ ПРОФЕССИОНАЛЬНЫХ РИСКОВ, ПРИЕМЛЕМОЙ ДЛЯ ПРЕДПРИЯТИЙ РАЗЛИЧНЫХ ВИДОВ ЭКОНОМИЧЕСКОЙ ДЕЯТЕЛЬНОСТИ}

\section{И. Н. Ткалич}

Государственное учреждение «Национальный научно-исследовательский институт промышленной

безопасности и охраны труда»

ул. Вавиловых, 13, г. Киев, 04060, Украина. E-mail: iratkalich@gmail.com

Отмечено, что действующая система управления охраной труда не обеспечивает определение приоритетности профилактических мероприятий по безопасности и гигиене труда, не способствует внедрению эффективного механизма экономического стимулирования работодателей к созданию надлежащих, безопасных и здоровых условий труда и не позволяет работодателям выбирать действенный способ управления охраной труда. Меры реагирования направляются преимущественно на регулирование и усиление обязательных общих требованийбез учета факторов риска на производстве. Проанализирован мировой опыт по оценке профессиональных рисков. Учитывая значительное количество существующих методов оценки рисков и невозможность создать универсальный метод, пригодный для предприятий (организаций) любого вида экономической деятельности, приведено краткое описание, преимущества и недостатки наиболее часто используемых в международной практике методов идентификации, анализа и оценки риска, их сочетание или последовательно-параллельного применения. Использование этих методов предполагает их адаптацию к условиям конкретного предприятия с учетом его специфики. Наиболее привлекательными для практического использования можно считать методы Элмери, Файн-Кинни и «Матрица последствий / вероятностей» через умеренные требования к необходимым ресурсам, низкую степень неопределенности результатов и невысокую сложность реализации. По результатам проведенных теоретических исследований разработана методика оценки профессионального риска, использование которой предполагает выполнение определенной последовательности этапов: организация работ, идентификация опасностей, анализа и оценки риска, разработка и внедрение мероприятий. Заключительный этап методики предусматривает целенаправленное использование полученных на предыдущих этапах данных для обоснования мероприятий, направленных на устранение (по возможности) или минимизацию рисков. Для практической реализации изложенной методики необходимо разработать и внедрить информационную систему «Реестр профессиональных рисков». Эта система позволит автоматизировать все этапы, начиная от сбора данных, прежде всего, о потенциальных опасностях и их источниках, и заканчивая расчетом оценки профессиональных рисков на основе выбранных методов.

Ключевые слова: управление охраной труда, методы оценки рисков, информационная система. 
АКТУАЛЬНІСТЬ РОБОТИ. Реалізація виробничих процесів і трудових операцій, нерозривно пов'язана 3 небезпечними і шкідливими виробничими факторами та іншими небезпеками, принципово не може бути абсолютно безпечною для працюючого, оскільки практично завжди існує випадкова можливість виникнення ситуації, коли вплив небезпек на організм працюючого стає невідворотним.

Такі випадкові можливості несприятливих подій 3 урахуванням значущості їх наслідків називають ризиками.

Ризик - ймовірність виникнення негативних наслідків від провадження господарської діяльності та можливий розмір втрат від них, що вимірюється у кількісних та якісних показниках.

Згідно ДСТУ 2293:2014 «Охорона праці. Терміни та визначення основних понять» професійний ризик - ризик ушкодження здоров'я працівника в процесі його професійної діяльності.

Гігієнічною класифікацією праці за показниками шкідливості та небезпечності факторів виробничого середовища, важкості та напруженості трудового процесу професійний ризик визначено як величина ймовірності порушення (ушкодження) здоров'я працівника з урахуванням тяжкості наслідків внаслідок несприятливого впливу факторів виробничого середовища і трудового процесу.

Величезна різноманітність ризиків, методологічних концепцій теорії ризику і методичних підходів до аналізу та оцінювання ризиків не дозволили міжнародній спільноті фахівців з безпеки праці прийти до теперішнього часу до єдиного практичного підходу до оцінки професійного ризику в системі управління охороною праці на будь-якому підприємстві незалежно від виду його діяльності, заснованого на загальних теоретичних постулатах.

Питанням методичних підходів до оцінки та процесам керування професійними ризиками присвячені роботи таких вчених як Aven T., Krause T.R., Laitinen Н.,Богданова О.В., Бочковский А.П., Гогіташвілі Г.Г., Кружилко О.С., Сукач С.В., Цина А.Ю. та ін. [1-10].

Мета роботи. Провести аналіз методів загальної оцінки ризиків. Визначити найбільш привабливі для практичного використання методи для кожного 3 етапів проведення оцінки професійного ризику. Розробити методику оцінки професійного ризику.

МАТЕРІАЛ I РЕЗУЛЬТАТИ ДОСЛІДЖЕНЬ. Згідно статті 4 Закону України «Про охорону праці» державна політика в галузі охорони праці визначається відповідно до Конституції України Верховною Радою України і спрямована на створення належних, безпечних і здорових умов праці, запобігання нещасним випадкам та професійним захворюванням. Державна політика в галузі охорони праці базується на принципах:

- пріоритету життя і здоров'я працівників, повної відповідальності роботодавця за створення належних, безпечних і здорових умов праці;

- підвищення рівня промислової безпеки шляхом забезпечення суцільного технічного контролю за станом виробництв, технологій та продукції, а також сприяння підприємствам у створенні безпечних та нешкідливих умов праці;

- використання світового досвіду організації роботи щодо поліпшення умов і підвищення безпеки праці на основі міжнародного співробітництва.

В умовах сьогодення діюча система управління охороною праці на всіх рівнях сформована за принципом реагування на небезпечні випадки та ситуаціiі, а не за принципом профілактики небезпечних випадків та ситуацій, що унеможливлює визначення пріоритетності профілактичних заходів з безпеки та гігієни праці на кожному з етапів діяльності підприємства. Такий підхід не сприяє запровадженню ефективного механізму економічного стимулювання роботодавців до створення належних, безпечних i здорових умов праці і не дає змоги роботодавцям вибирати найефективніший спосіб управління та інтегрувати систему управління охороною праці в загальну систему управління підприємством. Через відсутність ефективного аналізу причин нещасних випадків на виробництві заходи реагування спрямовуються переважно на регулювання та посилення обов'язкових загальних вимог без урахування факторів ризику на виробництві.

Відсутність в Україні єдиної державної системи статистичної звітності стосовно нещасних випадків на виробництві, аварій та професійних захворювань, шкідливих умов праці, випадків погіршення здоров'я, пов'язаних 3 професійною діяльністю, унеможливлює проведення аналізу витрат і вигод у процесі забезпечення належного рівня безпеки та гігієни праці.

Розпорядженням Кабінету Міністрів України від 12 грудня 2018 р. № 989-р «Про схвалення Концепції реформування системи управління охороною праці в Україні та затвердження плану заходів щодо iii реалізації» 3 метою створення національної системи запобігання виробничим ризикам для забезпечення ефективної реалізації права працівників на безпечні та здорові умови праці передбачено перехід від заходів реагування на нещасні випадки та системи безпеки та гігієни праці, що базуються на усуненні наслідків, до заходів, які передбачають точне і постійне оцінювання виробничих ризиків, їх запобігання, а також заохочення до створення безпечних і здорових умов праці.

Національний стандарт України ДСТУ IEC/ISO 31010:2013 «Керування ризиком. Методи загального оцінювання ризику» найбільш повно описує процедуру та методи загального оцінювання ризиків. Але, в той же час, стандарт не містить детального, певного для будь-якої організації методу оцінки ризику. Керуючись положеннями стандарту, необхідно самостійно вибирати методи оцінки ризику, в тому числі і не наведені в цьому стандарті, з урахуванням ï застосовності в конкретних випадках і в залежності від конкретної ситуації, а також вимог національного законодавства.

В силу принципової неможливості створити один єдиний універсальний метод оцінки ризиків, придатний для будь-яких організацій будь-якого виду економічної діяльності, наведено короткий опис, переваги та недоліки найбільш часто викорис- 
товуваних в міжнародній практиці методів ідентифікації, аналізу і оцінювання ризику, їх поєднання або послідовно-паралельного застосування $[2,5]$.

Метод «Переліки контрольних запитань» (англ. - Check List)

Широко використовується на практиці як самостійний, так в поєднанні з іншими методами. Переліки контрольних запитань - це переліки небезпечних факторів, ризиків, розроблені на основі накопиченого досвіду, а також за результатами попереднього оцінювання ризику. Можуть застосовуватись на любому етапі виконання робіт, у тому числі і як частина інших методів ідентифікації небезпек та оцінки ризику.

Переваги. Перевага методу в його простоті. Будучи належним чином розробленими, перевірочні листи об'єднують повноту обліку даних. Найбільш ефективний при оцінці ризику на стабільних, давно організованих робочих місцях з усталеною практикою експлуатації і з добре відомими технологіями, обладнанням, сировиною, матеріалами і т.п., а також 3 добре відомими небезпеками.

Недоліки. Недоліком методу є можливість неякісного складання питань, а також пропуску важливих моментів.

Метод «Що - якщо» [англ. - Structured What-If Technique (SWIFT)]

Заснований на вивченні стану умов експлуатації системи (об'єкта) або відповідності стану умов праці чинним вимогам безпеки. Метод дає уявлення про відхилення від штатного режиму і може служити основою для більш докладних (в тому числі і кількісних) методів оцінки ризику, дозволяє виробити коригувальні дії не тільки з боку системи контролю та управління безпекою, але і внести корективи в технологічний процес або модернізувати систему і робоче місце.

Переваги. Можливість застосування до всіх видів виробництва і систем, їх елементам, ситуацій і обставин, процесам, процедурам, видам діяльності і організаціям в цілому. Можливість застосування результатів ідентифікації ризиків та небезпечних факторів для кількісного дослідження ризику.

Недоліки. Потребує залучення високо кваліфікаційних спеціалістів. Застосування методу на загальному рівні може не давати змоги виявити складні, докладні чи взаємопов'язані причини.

Метод Елмері (англ. - ELMERI system)

Елмері - надійний метод контролю безпеки праці в промисловості. Метод Елмері можна легко і швидко використовувати в будь-якій галузі промисловості і на підприємствах будь-яких розмірів. Метод заснований на спостережені за умовами праці на робочому місці. Ці спостереження охоплюють всі найважливіші складові безпеки праці, такі як: використання засобів захисту, порядок на робочому місці, безпеку при роботі з технікою, гігієну праці та ергономіку. За результатами дослідження по кожному робочому місту заповнюється спеціальна анкета, в якій на проти кожного з пунктів проставляється лише дві оцінки «добре» чи «незадовільно». Після виставлення оцінок розраховується індекс Елмері.
Переваги. Простота, зрозумілість та швидкість проведення. Не вимагає спеціальних навичок і компетенції та надає можливість застосування на будьякому підприємстві чи в організації.

Недоліки. Через те, що всі фактори, які впливають на безпеку праці, приймаються рівнозначними, підсумкове значення коефіцієнта безпеки складно використовувати для вироблення заходів 3 управління ризиком, бо неможливо визначити, який саме фактор або фактори стали основною причиною підвищеного ризику на робочому місці.

\section{Матриця наслідків / ймовірностей (англ. - Riskmatrix)}

Засіб поєднання якісних та напівкількісних оцінок наслідків ймовірностей для отримання рівня ризику чи ранжування ризику. Зазвичай застосовують як засіб попередньої оцінки, коли виявлено кілька різних ризиків і потрібно визначити який ризик найбільш значущий, щоб розставити пріоритети в управлінні ризиками

Переваги. Простий у застосуванні. Дає змогу швидко ранжувати ризики за різними рівнями важливості

Недоліки. Результати залежать від рівня докладності аналізування, що в свою чергу, призводить до недооцінювання фактичного рівня ризику. Потребує залучення висококваліфікаційних спеціалістів.

Метод Файн-Кінні (англ. - Fine \& Kinney Method)

Метод полягає в послідовній оцінці ризиків як добутку трьох складових - ступеня схильності працівника до впливу небезпеки на робочому місці, можливості виникнення небезпеки та тяжкості наслідків для працівників у випадку, якщо небезпека здійсниться.

У кожному конкретному випадку визначається, яким чином те або інше порушення вимог охорони праці може привести до виробничої травми або професійного захворювання. Розглядаються всі стадії робіт - від процесу підготовки до стадій їх завершення.

Переваги. Переваги методу полягають в простоті розрахунків та наочності.

Недоліки. До недоліків методу слід віднестисуб'єктивність при проведенні оцінки. Потребує залучення значних ресурсів та витрат часу на реалізацію.

Метод «Дослідження небезпеки та працездатності» [англ. - Hazard and Operability study (HAZOP)]

Метод HAZOP результативніший на стадії завершення розробки проекту, коли відпрацьовані основні конструктивні та технологічні рішення, а також на стадії підготовки робочої документації після розробки схем технологічного процесу або в процесі модифікації устаткування, що експлуатується, оскільки ще до початку аналізу HAZOP необхідно забезпечити доступ експертів до докладної інформації про проект і про технологічні процеси. Метод дає змогу ідентифікувати ризики для персоналу, устаткування, довкілля та/або цілей організації. Крім ідентифікації небезпек і їх ранжирування дозволяє виявити неясності і неточності в інструкціях з безпеки і сприяє їх подальшому вдосконаленню. 
Переваги. Перевагами методу є забезпечення детального та комплексного дослідження системи та можливість його поетапного застосування для досить широкого спектру процесів і систем, а реєстрація проміжних результатів. Дає змогу виявляти та враховувати причини та наслідки людських помилок.

Недоліки. Вимагає наявності докладної документації про об’єкт аналізу. Складний для аналізу комбінацій подій, що призводять до аварійних (небезпечним) ситуацій. Потребує залучення значних ресурсів та витрат часу на реалізацію.

Аналізування видів і наслідків відмов [англ. Failure Mode Effect Analysis (FMEA)] / [англ. Failure Mode, Effect and Criticality Analysis (FMECA)]

Застосовується для аналізу складних технічних систем, за допомогою метода ідентифікуються відмови окремого елемента системи, які можуть привести до невиконання його призначених функцій i надалі - до нештатного аварійного стану і / або до виникнення небезпечних ситуацій. FMECA розширює FMEA, охоплюючи ранжування кожного ідентифікованого виду відмови відповідно до його важливості або критичності.

Переваги. Можливість ідентифікації небезпек на начальних етапах створення технічних систем (етапі проектування тощо), врахування можливих помилок оператора таких систем (проявів людського фактора), визначення рангу пріоритетності ризику.

Недоліки. Методи застосовуються для виявлення окремих типів відмов, але не їх поєднань (наприклад, поєднання відмов технічних пристроїв і людського фактора). Розглядають всі відмови, навіть ті, які не представляють собою небезпеки, в зв'язку з цим вимагають значних витрат часу. Трудомісткі i тривалі щодо складних систем.

Аналізування рівнів захисту [англ. - Layer protection analysis, (LOPA)]

Метод оцінювання ризиків, пов'язаних з небажаними подією чи сценарієм. Полягає у визначені пари причина-наслідок та ідентифікації рівнів захисту $з$ подальшим обчисленням порядку величини для визначення адекватності захисту для зменшення ризику до прийнятного рівня.

Переваги. Відносна простота. Не потребує залучення значних ресурсів та витрат часу на реалізацію. Дає змогу ідентифікувати операції, системи та процеси, засоби захисту яких є недостатніми.

Недоліки. Неможливість в процесі виконання методу одночасного розгляду декількох пар причинанаслідок.

Технічне обслуговування, зоріснтоване на забезпечення безвідмовності [англ. - Reliability centered main tenance (RCM)]

Метод ідентифікації політик, які треба запроваджувати для керування відмовами, щоб ефективно та результативно досягати необхідного рівня безпеки, готовності та економічності функціонування всіх типів устаткування.

Переваги. Застосування в широкому спектрі галузей промисловості.
Недоліки. Потребує належної обізнаності з устаткуванням та структурою, умовами експлуатації та відповідними системами, можливими відмовами та наслідками цих відмов.

Загальне оцінювання надійності людини [англ. - Human Reliability Assessment (HRA)]

Розглядає вплив операторів та обслуговуючого персоналу на функціонування системи і може застосовуватися для оцінювання впливу помилок оператора на продуктивність і безпеку системи.

Переваги. Надання формалізованого способу включення людського фактора в ідентифікацію небезпек і оцінку ризиків, пов'язаних з виконанням робіт, включаючи управління системами, в яких дії персоналу мають істотне значення.

Недоліки. Складність і різноманітність психічних, фізіологічних і компетентнісних характеристик, поведінкових особливостей людського організму і особистості працюючого, які ускладнюють визначення простих типів небезпек і ризиків.

Методи оцінки ризиків можуть бути якісними, кількісними чи напівкількісними. Для проведення оцінки ризику пропонується використовувати методи та/або їх комбінацій за критеріями застосовності. Таких критеріїв три - завжди застосовний, застосований та незастосовний.

Так, для проведення процесу ідентифікації небезпек пропонується застосовувати в основному якісні методи (переліки контрольних запитань, SWIFT, метод Елмері), які полягають в дослідженні умов праці в цілому та/або складових факторів.

На стадіях аналізування та оцінювання ризику вагомих результатів можна досягти при застосуванні кількісних методів («Матриця наслідків/ймовірностей», метод Файн-Кінні) або методів оцінки ступеня ризику, виходячи 3 окремих оцінок можливості (ймовірності) і значущості (тяжкості) наслідків реалізації ризику. Оскільки при оцінці ризику підлягають оцінюванню не тільки ризики впливу окремих небезпек, але вся їх сукупність при всіх можливих ситуаціях, яка динамічно розвивається від штатної ситуації до аварійної, то доводиться розглядати небезпеки і ризики складного ланцюжка різних подій, поведінку складних технічних систем або процесів. У цих випадках, як правило, застосовують бальні оцінки тих чи інших ступенів ризику, що дозволяє в подальшому використовувати математичні методи побудови інтегральної оцінки або напівкількісні методи (НAZOP, FMEA / FMECA, LOPA, RCM, HRA).

На вибір методу оцінки ризику впливають наступні чинники (табл. 1):

1) ресурси - компетентність, досвід, кваліфікація експертної групи оцінювання ризику, матеріально-технічне забезпечення;

2) характер та ступінь невизначеності - якість, кількість та повнота наявної інформації щодо ризику, його джерела та причини виникнення ризику, наслідки;

3) складність - кількість та номенклатура необхідних даних, спеціалізованих засобів для проведення розрахунків, як наслідок, витрат часу тощо. 
Таблиця 1 - Обгрунтування вибору / застосування методів оцінки ризиків

\begin{tabular}{|c|c|c|c|}
\hline $\begin{array}{c}\text { Найменування } \\
\text { метода }\end{array}$ & Ресурси & $\begin{array}{c}\text { Характер } \\
\text { і ступінь невизначеності }\end{array}$ & Складність \\
\hline Переліки контрольних запитань & низька & низька & низька \\
\hline Метод «Що - якщо» (SWIFT) & середня & середня & будь-яка \\
\hline Метод Елмері & низька & низька & низька \\
\hline $\begin{array}{l}\text { Матриця наслідків / } \\
\text { ймовірностей }\end{array}$ & середня & низька & висока \\
\hline Метод Файн-Кінні & середня & середня & середня \\
\hline $\begin{array}{l}\text { Метод «Ідентифікації } \\
\text { небезпек» (HAZID) }\end{array}$ & середня & середня & середня \\
\hline $\begin{array}{l}\text { Метод «Дослідження небезпеки } \\
\text { та працездатності» (HAZOP) }\end{array}$ & середня & висока & висока \\
\hline $\begin{array}{l}\text { Аналізування видів і наслідків } \\
\text { відмов (FMEА) /Аналізування } \\
\text { видів, наслідків і критичності } \\
\text { відмов (FMECA) }\end{array}$ & середня & середня & середня \\
\hline $\begin{array}{l}\text { Аналізування рівнів захисту } \\
\text { (LOPA) }\end{array}$ & середня & середня & середня \\
\hline $\begin{array}{l}\text { Технічне обслуговування, зорі- } \\
\text { єнтоване на забезпечення } \\
\text { безвідмовності (RCM) }\end{array}$ & середня & середня & середня \\
\hline $\begin{array}{l}\text { Загальне оцінювання надійності } \\
\text { людини (HRA) }\end{array}$ & низька & середня & низька \\
\hline
\end{tabular}

Використання вказаних методів передбачає їх адаптацію до умов конкретного підприємства або галузі з урахуванням їх специфіки. Як видно з таблиці 1, найбільш привабливими для практичного використання можна вважати методи Елмері, ФайнКінні та «Матриця наслідків / ймовірностей» через помірні вимоги до необхідних ресурсів, низьку ступінь невизначеності результатів та невисоку складність реалізації. Саме такий спосіб вибору методів забезпечить їх використання на підприємствах різних видів економічної діяльності. Урахування специфіки конкретного підприємства може бути досягнуто через гнучкий механізм системи анкетування, що дозволяє реалізувати метод Елмері.

Керуючись настановами ДСТУ ISO 31000:2018 (ISO 31000:2018, IDT) «Менеджмент ризиків. Принципи та настанови» оцінку професійних ризиків пропонується проводити за наступними етапами:

1. організація робіт - збір, аналіз та узагальнення статистичних даних. Визначення цілей та завдань оцінки ризику, які випливають 3 причин, що викликали необхідність проведення оцінки ризику. Визначення робочих місць та/або видів робіт, для яких проводиться оцінка ризику. Вибір методів оцінки ризику.
2. Іоентифікація небезпек - процес розпізнавання наявності небезпечних та шкідливих факторів та визначення іï характеристик.

3. Аналізування ризику - визначення наслідків і ймовірностей виникнення цих наслідків.

4. Оцінювання ризику - процес порівняння отриманих результатів аналізування ризиків 3 критеріями ризиків, визначення їх прийнятності.

5. Розробка та впровадження заходів цілеспрямоване використання отриманих на попередніх етапах даних для обгрунтування заходів, спрямованих на усунення (за змогою) або мінімізацію ризиків.

Методика оцінки професійного ризику передбачає виконання визначеної послідовності етапів (рис. 1).

Для практичної реалізації запропонованої методики необхідно розробити та впровадити на підприємствах інформаційну систему «Реєстр професійних ризиків», яка забезпечить автоматизацію збору та обробки необхідних даних, проведення розрахунків та формування звітних документів щодо оцінки професійних ризиків на основі обраних методів. Отримані результати дозволять обгрунтувати заходи 3 керування ризиками, профілактики виробничого травматизму та професійної захворюваності. 


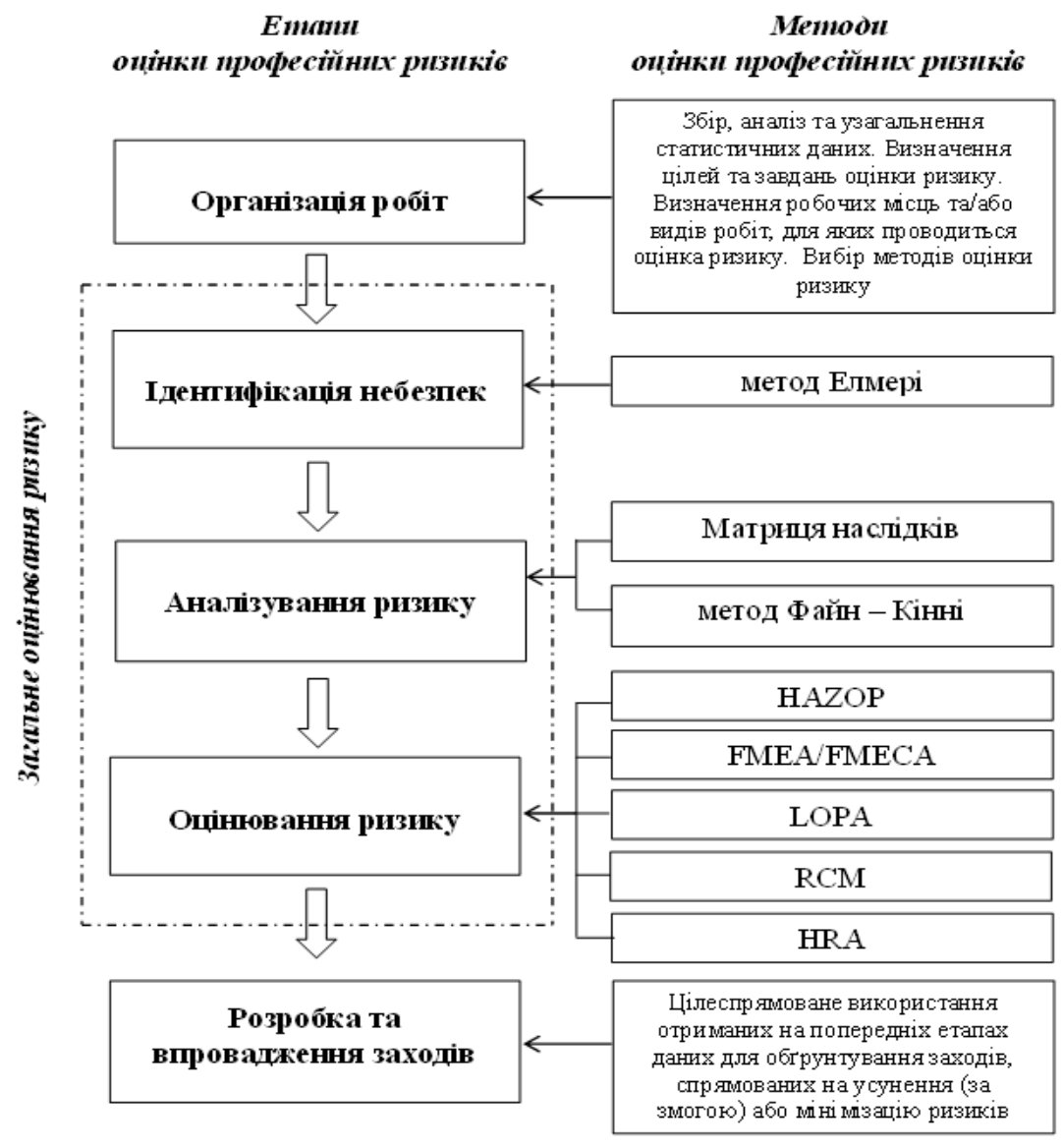

Рисунок 1 - Методика оцінки професійного ризику

ВИСНОВКИ. На основі проведено аналізу методів загального оцінювання ризику, встановлено, що найбільш привабливими для практичного використання на етапах ідентифікації небезпек та аналізування ризику можна вважати методи Елмері, ФайнКінніта «Матриця наслідків / ймовірностей» через помірні вимоги до необхідних ресурсів, низьку ступінь невизначеності результатів та невисоку складність реалізації. За результатами проведених теоретичних досліджень розроблено методику оцінки професійного ризику, використання якої передбачає виконання визначеної послідовності етапів: організація робіт, ідентифікація небезпек, аналізування та оцінювання ризику, розробка та впровадження заходів. Заключний етап методики передбачає цілеспрямоване використання отриманих на попередніх етапах даних для обгрунтування заходів, спрямованих на усунення (за змогою) або мінімізацію ризиків. Для практичної реалізації запропонованої методики необхідно розробити та впровадити інформаційну систему «Реєстр професійних ризиків». Ця система дозволить автоматизувати всі етапи, починаючи від збору даних, насамперед, про потенційні небезпеки та їх джерела, та закінчуючи розрахунком оцінки професійних ризиків на основі обраних методів.

\section{ЛІТЕРАТУРА}

1. Aven T. Risk assessment and risk management: Review of recent advances on their foundation. European Journal of Operational Research. 2016. № 253. P. 1-13.
2. Laitinen H., Rasa P.-L., Räsänen T., Lankinen T., Nykyri E. ELMERI Observation Method for Predicting the Accident Rateand the Absence Dueto Sick Leaves. American Journal of Industrial Medicine. 01 Sep 1999, Suppl. 1. pp. 86-88.

3. Krause T. New perspectives in fatality andserious injury prevention. Presentation at Fatality PreventionForum 2012, Coraopolis, PA, USA.

4. Богданова О. В. Комбінований метод оцінки ризику травматизму для промислового підприємства. Проблеми охорони праці в Україні. 2016. Вип. 31. C. 52-63.

5. Бочковський А. П. Теоретичні аспекти універсалізації оцінки професійного ризику в системах управління охороною праці. Вісник Львівського державного університету безпеки життєдіяльноcmi. Львів, 2016. № 14. С.134-151.

6. Гогіташвілі Г. Г., Степанишин В. М., Тисовський Л. О. Аналіз статистичних даних щодо причин та наслідків виробничого травматизму працівників. Вісник Національного університету «Львівська політехніка». 2011. № 707. С. 42-45.

7. Кружилко О. Є., Богданова О. В. Алгоритм вибору методів та визначення результативності оцінки ризику. Вісник Кременчуцького національного університету імені Михайла Остроградського. 2016. Вип. 2/2016 (97), част. 1. С. 76-81.

8. Кружилко О. Є., Сторож Я. Б., Ткалич I. М., Полукаров О. І. Підвищення ефективності управління охороною праці на основі виявлення небезпек та оцінки ризиків виробничого травматизму. Адаптив- 
ні системи автоматичного управління. 2017. № 2 (31). C. 38-45.

9. Сукач С. В., Кобылянский М. А., Левченко Л. А. Концептуальный подход к построению комплексной автоматизированной системы мониторинга и управления физическими факторами в зданиях и сооружениях. Вісник Кременчуцького національного уні- верситету імені Михайла Остроградського. 2015. Вип. 1/2015 (90), част. 1. С. 51-56.

10. Цина А. Ю.,Зелененко А. О., Костенко Н. С. Ідентифікація небезпечних чинників та оцінювання ризиків на виробництві.Проблеми охорони праці в Україні. 2015. Вип. 30. С. 105-120.

\section{THEORETICAL FRAMEWORK FOR CONSTRUCTION OF METHODS OF PROFESSIONAL RISK AS- SESSMENT ACCEPTABLE FOR ENTERPRISES OF DIFFERENT TYPES OF ECONOMIC ACTIVITY}

\section{Tkalych}

Public Agency «National Scientific Research Institute of Industrial Protection and Occupational Safety»

vul. Vavilovykh, 13, Kyiv, 04060, Ukraine. E-mail: iratkalich@ gmail.com

Purpose. The purpose of the given research is to analyze the general risk assessment methods, identify the most attractive methods for practical use for each of the phases of professional risk assessment, develop a methodology for assessing occupational risk. It is noted that the current system of labor protection management does not ensure the prioritization of preventive measures on occupational safety and health, does not promote the introduction of an effective mechanism for economic incentives for employers to create appropriate, safe and healthy working conditions and prevents employers from choosing an effective way of managing occupational safety and health. Response measures focus on regulating and strengthening mandatory general requirements without taking into account risk factors in the workplace. Methodology. Taking into account a large number of existing risk assessment methods and the inability to create a universal method suitable for enterprises (organizations) of any kind of economic activity, a brief description of the advantages and disadvantages of the most commonly used methods of identification, analysis and risk assessment, their combination or sequential-parallel application was given. The use of these methods involves their adaptation to the conditions of a particular enterprise, taking into account its specificity. Results. The world experience in professional risk assessment was analyzed. The most attractive for practical use are the «Elmerisystem», «Fine\&Kinney» and the «Risk matrix» due to moderate requirements for the required resources, low degree of uncertainty of results and low implementation complexity. Practical value. According to the results of the theoretical researches, a method for assessing occupational risk, the use of which involves the implementation of a defined sequence of stages: the organization of work, identification of hazards, analysis and risk assessment, development and implementation of measures was developed. The final stage of the methodology involves the purposeful use of the data obtained in the previous stages to justify measures aimed at eliminating (if possible) or minimizing risks. Conclusions. For practical implementation of the above-mentioned methodology it is necessary to develop and implement the information system "Register of Professional Risks". This system will automate all stages, from the collection of data, first of all, about the potential dangers and their sources, and ending with the calculation of professional risk assessment based on selected methods.

Key words: labor protection management, risk assessment methods, information system.

\section{REFERENCES}

1. Aven, T. (2016), Risk assessment and risk management: Review of recent advances on their foundation, European Journal of Operational Research, no 253 , pp. 1-13.

2. Laitinen, H., Rasa, P.-L., Räsänen, T., Lankinen, T., Nykyri, E. (1999), ELMERI Observation Method for Predicting the Accident Rate and the Absence Due to Sick Leaves, American Journal of Industrial Medicine, Suppl. 1, pp. 86-88.

3. Krause, T. (2012), New perspectives in fatality and serious injury prevention. Presentation at Fatality Prevention Forum, Coraopolis, PA, USA.

4. Bogdanova, O. V. (2016), Combined method of assessing the risk of injury for an industrial enterprise. Problems of labor protection in Ukraine, no. 31, pp. $52-$ 63.

5. Bochkovski, A. P. (2016), Theoretical aspects of the universalization of professional risk assessment in occupational safety management systems, Visnyk of the Lviv State University of Life Safety, no. 14, pp. 134-151.

6. Gogitashvili, G. G., Stepanishin, V. M., Tysovsky, L. A. (2011), Analysis of statistical data on the causes and consequences of occupational injuries of employees, Bulletin of Lviv Polytechnic National University, no. 707, pp. 42-45.
7. Kruzhilko, O. E., Bogdanova, O. V. (2016), Algorithm for selecting methods and determining the effectiveness of risk assessment, Transactions of Kremenchuk Mykhailo Ostrohradskyi National University, no 97, pp. 76-81.

8. Kruzhilko, O. E., Storozh, Ya. B., Tkalych, I. M., Polukarov, O. I. (2017), Improvement of the effectiveness of management of labor protection on the basis of hazard identification and risk assessment of occupational injuries, Adaptive automatic control systems, no. 2 (31), pp. 38-45.

9. Sukach, S. V., Kobilyansky, M. A., Levchenko, L. A. (2015), Conceptual approach to the construction of a complex automated system for monitoring and control of physical factors in buildings and constructions, Transactions of Kremenchuk Mykhailo Ostrohradskyi National University, no. 1/2015 (90), part. 1, pp. 51-56.9.

10. Zina, A. Yu., Zelenenko, A. O., Kostenko, N. S. (2015), Identification of hazardous factors and risk assessment at work, Problems of labor protection in Ukraine, no. 30, pp. 105-120. 